\title{
Effect of different weaning time on the growth and survival of Common carp (Cyprinus carpio L.) larvae
}

\author{
Dániel Minya - László Kovács - Dávid Homoki - Milán Fehér - Péter Bársony - László Stündl \\ University of Debrecen Faculty of Agricultural and Food Sciences and Environmental Management, \\ Institute of Animal Science, Biotechnology and Nature Conservation, Debrecen, Hungary \\ minya.dani@agr.unideb.hu
}

\section{SUMMARY}

\begin{abstract}
Within our experiment, we studied the combined effect of live food application and feed training on the production parameters of carp larvae. In addition, we examined whether there is a difference in the growth rate and survival rate of the specimens of Szeged mirror landrace reared in similar stocking density but with different treatments.

Specimens of Szeged mirror landrace from induced propagation were placed into 12 pieces of 40-liter aquaria. For the 4 different treatments, (K, A3, A6, A9), live food (Artemia salina) was fed, as well as feed training was applied.

We also sought to find an answer as to how our feeding and rearing conditions can affect the production parameters of common carp fries and what impact these conditions may have on their survival rates. At the end of the 2-week experiment we determined the individual weight gain of the carp fries, their survival rate and the biomass growth. The purpose of the study is to examine the optimum timing of shifting from live food to feed for carp larvae.
\end{abstract}

Keywords: carp, live food, feed training, production parameters

\section{INTRODUCTION}

One of the most important fish species in the world's freshwater aquaculture production is carp. In 2014, a total of 4.1 million tonnes of carp were produced and taking into account the trends of recent decades, there is a continuous increase in its production (FAO 2017). Domestic carp breeding is typically carried out in pond farms, and a large proportion of the fish for market use comes from these farms. Domestic fish farming has a history of more than 100 years, which was generated by the need for replacement of the decreasing amount of edible fish stocks as a result of river regulations in the $19^{\text {th }}$ century (Lajkó and Tasnádi 2001). According to the data of the Agricultural Research Institute of 2016, a total of 15440 tonnes of carp were fished in that given year, out of which 10035 tonnes of fish had the appropriate size for market sale while the edible fish accounted for $42.7 \%$ of the total production (AKI 2017). There are both rearing-technological and production-structural reasons behind this centricity in carp breeding. The common carp is one of the best adaptable species for fish farming production on the basis of its profitability regarding structure, yield and revenue (Szatmári 2003). Currently, the production of edible carp is mostly carried out in a three-year operation process and the greatest disadvantage of this type of production is the long payback period (Szücs 2002).

The ever-intensifying pond farming production requires the knowledge and use of yield-enhancing methods. There is a demand among domestic pond fishermen for both reducing the financial risk of the investment and for shortening to some extent the 3 year-long production time of carp for market sale, thus making production more economical. One of the possible alternatives to reach this goal is the offseason (autumn) carp propagation. Before the seasonal propagation, the pre-rearing of fries is possible in an intensive system for up to two months. The pre-reared fish that are then stocked in fish farms will reach a higher average body weight by autumn, and their survival rate will also be higher due to their twomonth advantage, compared to the fish from seasonal propagation (March) (Zakes and Szczepkowski 2004, Zarsky et al. 2017).

The aim of the activity is to intensify the production of pond farming by shortening the breeding period and by developing the rearing and feeding technology. One of the most important factors of complex technology is the early stage of larvae rearing in a closed recirculation aquaculture system. Properly adjusted rearing conditions and feeding patterns basically determine the weight gain and survival rate of larvae reared in recirculation aquaculture systems.

This technology becomes truly economical if it is combined with an intensive, winter pre-rearing in an indoor recirculation aquaculture system. The offseason propagation and the success of intensive larvae rearing can be a viable solution if it is integrated in carp production. The cultivation of pre-reared carp stocks with intensive farming technology can intensify production; however, it can only be realized if it is intended to produce fish of appropriate sizes for market sale during a whole breeding season. An essential prerequisite for this new type of production structure is the effective breeding of and the highest possible survival rate for the extremely sensitive larvae.

In domestic carp production, a well-proven method (Tamás et al. 1982) is applied in carp fry rearing, during which the feeding larvae after having been fed on dissolved boiled egg yolk are stocked into prerearing ponds. In the future, larvae rearing in closed systems may be a priority for carp production, which requires such techniques and feeding technology that 
are other than the ones currently in practice (Borné et al. 2015). During intensive fish rearing, the adequate feeding routine and high-quality fish food are two of the most important influencing factors for the highly sensitive, newly hatched and fast growing larvae (Hamre et al. 2013). For larvae rearing of different fish species in closed monocultures, even today, different types of locally hatched zooplanktons, brine shrimp (Artemia salina) or rotifers (e.g. Brachionus plicatilis), are generally used. Fish that are farmed in fish ponds or those living under natural conditions have a relatively easy access to the necessary quality and quantity of feed components, however, artificial feed and live foods (e.g. Artemia nauplii) used in monocultures do not always provide the adequate nutrient content for the highly sensitive larvae. The use of live food in intensive systems can be an alternative to the currently applied feeding technologies intended for fish farm production even in the process of carp larvae rearing. As for the factors of rearing technology, during the larvae rearing of various species in intensive systems, feed training is of utmost importance besides water temperature, nitrogen concentrations and several other chemical or physical characteristics. Regarding the parameters of rearing technology, it is worth examining the proper feeding of the fish larvae (live food, starter feed) along with the effects these factors have on their survival.

In our experiment we studied the combined effect of live food application and feed training on production parameters for carp larvae. In addition, we examined whether there is a difference in the growth rate and survival rate of the specimens of Szeged mirror landrace reared in similar population density but with different treatments. The specimens of Szeged mirror landrace from artificial propagation were placed into 12 pieces of 40-litre aquaria, For the 4 different treatments (K, A3, A6, A9), live food (Artemia salina) was fed as well as feed training was applied. We were also trying to find an answer to how our feeding and rearing conditions can affect the production parameters of common carp fries and what impact they may have on their survival rates. At the end of the 2-week experiment we determined the individual weight gain of the carp fries, their survival rate and the biomass growth. The purpose of the study is to examine the optimal timing of shifting from live food to feed for carp larvae.

\section{MATERIAL AND METHODS}

\section{Parameters of treatments}

The experiment was carried out in the fish biology laboratory of the Faculty of Agricultural and Food Sciences and Environmental Management at the University of Debrecen. The carp larvae under examination were from the local population of Szeged landrace which were provided by NAIK-HAKI from the artificial reproduction of 16 May 2017. The fish hatched on 19 May 2017. The experiment started with the feeding of larvae on the $5^{\text {th }}$ day after hatching, on 24 May, after the absorption of the yolk sac.
During the experiment, 4 treatment settings were used with triple repetition over a 14-day period (Zhang 1994, Borné et al. 2015). We placed 200 pieces of carp larvae into 12 pieces of 40 litre capacity aquariums per unit, each equipped with pipe filters. The aquaria got a daily 10-20\% water change and substrate cleaning. Water temperatures and dissolved oxygen levels were monitored with the help of a device (Hach HQ 30d), and the nitrite concentration was measured by a colorimetric method (Aquamerck Nitrit-Test) on a daily basis in three randomly selected aquaria. The average water temperature during the experiment was $22.71 \pm 0.8{ }^{\circ} \mathrm{C}$, the average dissolved oxygen level was $7.83 \pm 0.6 \mathrm{mg} / \mathrm{l}$. These values proved to be optimum in the course of carp larvae rearing.

\section{Different treatments presented in detail}

- Control: The feeding was performed with enzymatic feed which was followed by fry rearing feed by the $7^{\text {th }}$ day of the experiment.

- A3: The fish were fed on brine shrimp and then on full nutrition feed for three days.

- A6: Fish were fed with brine shrimp for six days and then fry rearing feed.

- A9: They were given brine shrimp for nine days and then fry rearing feed up to the last $\left(14^{\text {th }}\right)$ day of the experiment.

Feed training lasted for one day in case of each setting. During this period, they variously received brine shrimp (Artemia salina) and fry rearing feed. During the experiment, the control group used 200$400 \mu \mathrm{m}$ particle size Biomar Larviva Prowean $(58 \%$ crude protein, $10 \%$ crude fat) starter feed for 7 days. The other three groups received Artemia feed and 300$500 \mu \mathrm{m}$ particle size minced Biomar Inico Plus $(58 \%$ crude protein, $15 \%$ crude fat) (Hasan and Macintosh 1992) (Table 1).

Table 1

Feed composition

\begin{tabular}{lcc}
\hline \multicolumn{3}{c}{ Feed components $(\%)$} \\
\hline \multicolumn{1}{c}{ Particle size } & $200-400 \mu \mathrm{m}$ & $300-500 \mu \mathrm{m}$ \\
\hline Crude protein & 58 & 58 \\
Crude fat & 10 & 15 \\
Crude ash & 11.7 & 11.2 \\
Crude fibre & 0.4 & 0.4 \\
Phosphorus & 1.7 & 1.7 \\
Calcium & - & 2.3 \\
Sodium & - & 1.04 \\
Aliphatic acids & 2.3 & - \\
\hline
\end{tabular}

For feeding with live food Artemia was used, similarly to applications described in studies by other authors (Verreth et al. 1992, Stéphanie et al. 1998, El Ghazali et al. 2010). Live food (Artemia) was produced by hatching commercially available fish eggs at $27{ }^{\circ} \mathrm{C}$ water temperature for 24 hours in 51 capacity bottles (Figure 1). During the experiment, ad libitum feed was used four times a day (Hasan et al. 1997).

Picture 1 shows the hatching of Artemia salina in 51 bottles made for this purpose. 


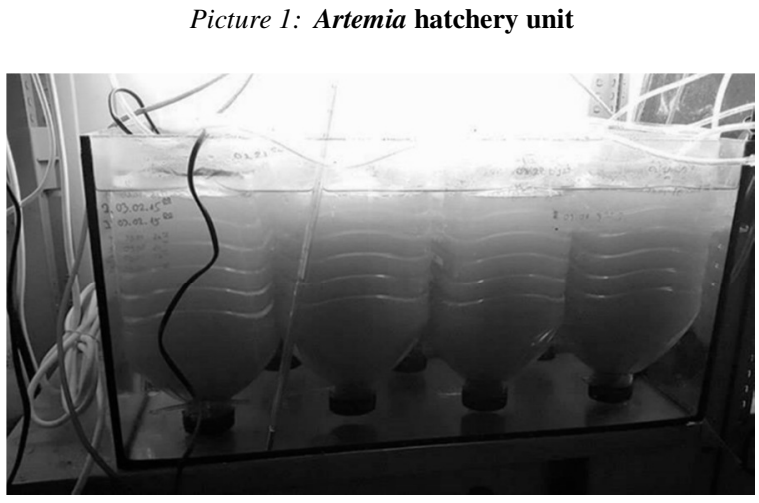

The aquaria with groups of different treatments were placed in block layout to reduce the effects of external environmental factors (Table 2).

Table 2

Layout of Aquaria

\begin{tabular}{|c|c||c|c|}
\hline $\mathrm{K}$ & $\mathrm{A} 3$ & $\mathrm{~A} 9$ & $\mathrm{~A} 6$ \\
\hline $\mathrm{A} 9$ & $\mathrm{~A} 6$ & $\mathrm{~K}$ & $\mathrm{~A} 3$ \\
\hline $\mathrm{A} 3$ & $\mathrm{~K}$ & A6 & A9 \\
\hline
\end{tabular}

Picture 2 shows the layout of the aquaria. Each aquarium is equipped with the above mentioned pipe filter system.

Picture 2: The experimental aquarium system

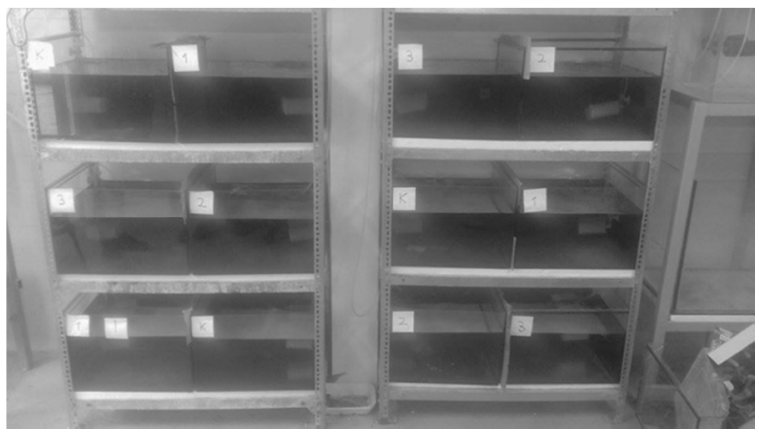

At the end of the experiment we measured the individual body weight of fish (with VWR SE 422 $0.01 \mathrm{~g}$ precision) of all the treatments and repetitions (Picture 3).

\section{Post-rearing}

After testing the experimental groups and measuring the individual weights, the stocks were transferred to a recirculation fish rearing unit with 350 1 tanks, where their post-rearing continued (Picture 4).

\section{Picture 3: Individual body weight measurement}

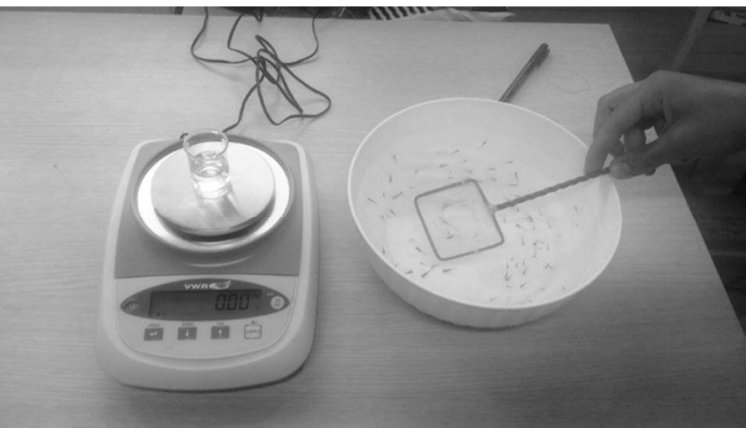

Picture 4: $\mathbf{3 5 0} \mathrm{l}$ recirculation fish farming units

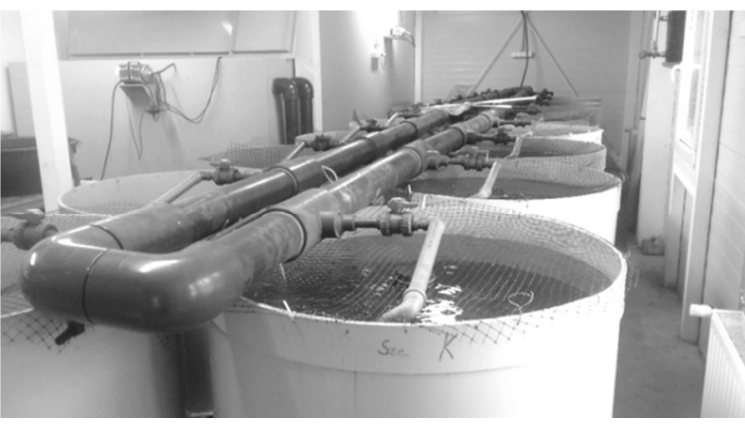

\section{Statistical evaluation}

Statistical evaluations were performed using IBM SPSS Statistics 22. The homogeneity test was performed by Levene test $(\mathrm{P}<0.05)$ within the groups. The effects of treatments and repetitions on the initial and final body weights of the carp fries were determined by single-factor analysis of variance (ANOVA). Significant differences between the body weights of the stocks were determined by LSD and Tukey-test $(\mathrm{P}<0.05)$. The method used in the experiment to examine the survival rate of the fish was adopted by OMMI (OMMI 2001).

\section{RESULTS}

The parameters we measured for water quality did not indicate any harmful levels for the carp larvae. The overall results for the groups are shown in Table 3 .

Overall results $(\mathbf{P}<\mathbf{0 . 0 5})$

\begin{tabular}{lcccc}
\hline & $\mathrm{C}$ & $\mathrm{A} 3$ & $\mathrm{~A} 6$ & $\mathrm{~A} 9$ \\
\hline Survival rate $(\%)$ & 2.5 & 76.67 & 89 & 94.17 \\
Individual body weight $(\mathrm{g})$ & - & $0.0314 \pm 0.0233^{\mathrm{a}}$ & $0.0207 \pm 0.0121^{\mathrm{b}}$ & $0.0205 \pm 0.0103^{\mathrm{b}}$ \\
Biomass (g) & 0.43 & 14.83 & 11.12 & 11.58 \\
\hline
\end{tabular}


The individual weights of the established groups were evaluated using IBM SPSS Statistics 22.50 specimens per treatment were measured (Catarina et al. 2009) and according to the test, groups A6 and A9 were homogeneous. The growth results of these treatments compared to those of group A3 show a significant difference. We found that the largest individual body weight was detected for A3 treatment, which proved to be even statistically different from the other treatments. There was no significant difference in the case of groups A6 and A9. In the control group, the individual body weights could not be statistically evaluated because of the small number of samples due to the low survival rate of the fish.

Figure 1 illustrates the development of individual weights per treatment. The highest values were obtained in group A3. During the two-week experimental period, the carp larvae reached $0.0314 \pm 0.0233 \mathrm{~g}$ of individual body weight and these results correspond to the data in other publications. Dabrowski et al. (1987) could reach for their fish $32.2 \pm 1.7 \mathrm{mg} /$ individual body weight in 11 days in 1987. Borné et al. (2015) reported $36.13 \pm 0.94 \mathrm{mg} /$ individual body weight in a two-week experiment. This treatment also reached the most favourable total weight in biomass. The results of the experiment showed that significant differences could be detected in growth among the groups. The survival rates correlate with the average weights in our case. For groups A6 and A9 it can be stated that a good survival rate of $89,94 \%$ or above was observed by the end of the experiment. For treatment A3, the $23 \%$ mortality rate is also an acceptable value in the early rearing stage. A significant $97 \%$ mortality rate was observed in the case of the control group. This can be explained with the feeding routine, as during the control treatment the larvae were fed exclusively on fish feed.

Figure 1: Changes in individual body weights (mg)

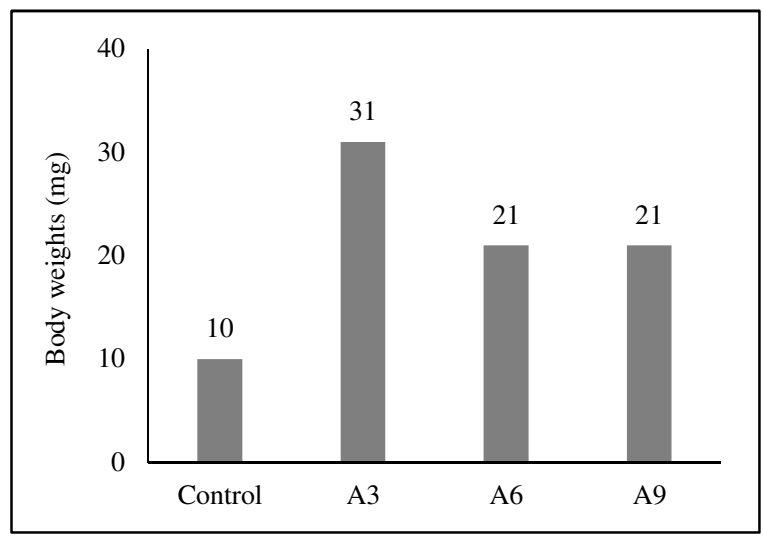

The underdeveloped organisms of the larvae can produce only very small amounts of enzymes, the effects of which can be supplemented by other enzymes through consuming planktonic organisms. Consequently, the total exclusion of live food and the resulting enzyme deficiency could probably lead to the extremely high mortality rate. The $97 \%$ mortality rate in the control group proves that feeding on live food should not be excluded from the process of carp larvae rearing. In the case of A3 treatment, higher individual weight gain was associated with lower survival, but even so, this group could reach the highest biomass growth. Survival percentages are shown in Figure 2.

Figure 2: Survival

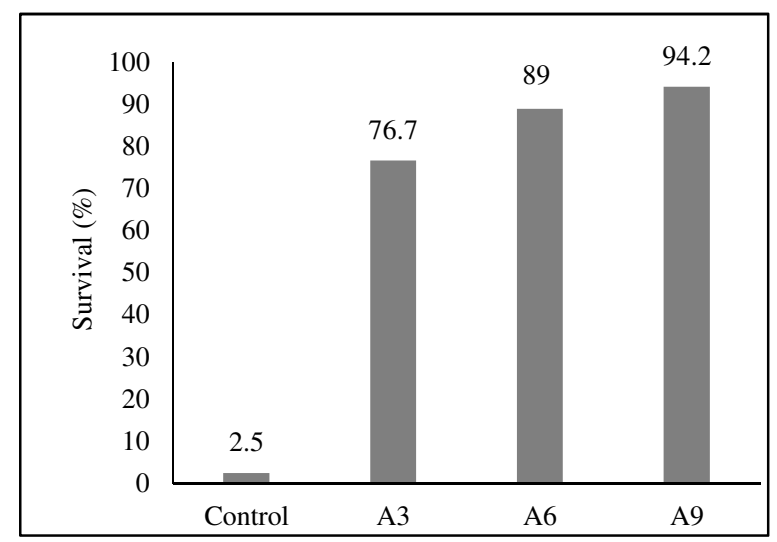

\section{CONCLUSIONS}

The results of the experiment showed that there was a statistically significant difference in the body weight gain of the groups. Among the homogenous groups at the start of the experiment, only those with A6 and A9 settings preserved their homogeneity until the end of the research. In the course of A3 treatment, there was a difference in homogeneity, in addition, the results of this particular group showed the highest values for body weight gain. For groups A6 and A9 it can be stated that a good survival rate of $89.94 \%$ or above was observed at the end of the experiment. For treatment A3 the $23 \%$ mortality rate is also an acceptable value in the early rearing stage. The $97 \%$ mortality rate in the control group can be attributed to feeding methods rather than to inappropriate rearing technology or water quality. Live food is indispensable to rearing carp larvae in an intensive system. The use of zooplankton cannot be replaced even by feed containing enzymes specifically made for larvae rearing. At the end of the experiment, the amount of harvested biomass showed that the duration of the use of live food and feed training affected the production parameters of the fish at this stage of fry rearing. Continuous weight gain was observed for all the groups, which concludes that carp can be adopted to our recirculation rearing system.

The aim of the experiment is to define how long it is worth feeding larvae on live food and to determine the optimum start time of feed training. The method used by us is suitable for successful larvae rearing. During the experiment it was confirmed that the use of live food is indispensable in the early stages of carp larvae rearing. However, for a favourable growth of larvae, it is necessary to start the dry feed training of the fish as soon as possible ( 3 days). For the sake of successful carp larvae rearing, the development of rearing technology elements as well as the improvement of feed call for further research in the future. 


\section{ACKNOWLEDGEMENT}

The work was supported by the European Regional and Development Fund and the Government of Hungary within the project GINOP-2.3.2-15-2016-
00025. The publication is supported by the EFOP3.6.3-VEKOP-16-2017-00008 project. The project is co-financed by the European Union and the European Social Fund.

\section{REFERENCES}

AKI - Agrárgazdaság Kutató Intézet (2017): XXII. évfolyam, 2017. szeptember. www.aki.gov.hu

Borné Papp Zs.-Nagyné Bíró J.-Adorján Á.-Bogárné Csávás K.Jakabné Sándor Zs. (2015): Élő táplálék (Artemia salina nauplius) előkészítése különböző vitaminok dúsításával pontylárvák (Cyprinus carpio L.) neveléséhez intenzív körülmények között. Halászat. 108. 4: 26-32.

Catarina, I. M. M.-Marco, G. P.-Stephan, S. W. E.-Ep, H. E.Johan, A. J. V. (2009): The accumulation of substances in Recirculating Aquaculture Systems (RAS) affects embryonic and larval development in common carp (Cyprinus carpio L.). Aquaculture. 291: 65-73.

Dabrowski, K.-Hinterleitner, S.-Sturmbauer, C.-El-Fiky, N.Wieser, W. (1987): Do carp larvae require vitamin C? Aquaculture. 72: 295-306.

El Ghazali, I.-Saqrane, S.-Carvalho, A. P.-Ouahid, Y.-Del, C. F.Oudra, B.-Vasconcelos, V. (2010): Effect of different microcyst in profiles on toxin bioaccumulation in common carp (Cyprinus carpio L.) larvae via Artemia nauplii. Ecotoxicology and Environmental Safety. 73: 762-770.

Hamre, K.-Yufera, M.-Rønnestad, I.-Conceição, L. E. C.Izquierdo, M. (2013): Fish larval nutrition and feed formulation: knowledge gaps and bottlenecks for advances in larval rearing. Reviews in Aquaculture. 5: 526-558.

Hasan, M. R.-Macintosh, D. J. (1992): Optimum food particle size in relation to body size of common carp, (Cyprinus carpio L.) fry. Aquaculture and Fisheries Management. 23: 315-325.

Hasan, M. R.-Macintosh, D. J.-Jauncey, K. (1997): Evaluation of some plant ingredients as dietary protein sources for common carp (Cyprinus carpio L.) fry. Aquaculture. 151: 55-70.

Lajkó I.-Tasnádi R. (2001): A tógazdasági haltenyésztés alapjai. Agroinform. Budapest.

OMMI - Országos Mezőgazdasági Minősítő Intézet (2001): Ponty teljesítményvizsgálati kódex 3. Országos Mezőgazdasági Minősítő Intézet. Budapest.
Segner, H.-Rosch, R.-Verreth, J.-Witt, U. (1993): Larval nutritional physiology: studies with Clarias gariepinus, Coregonus laÍaretus and Scophthalmus maximus. Journal of the World Aquaculture Society. 24: 121-134.

Stéphanie, F.-Inge, G.-Anne-Marie, E.-Pierre, B. (1998): Histological changes induced by dietary phospholipids in intestine and liver of common carp /Cyprinus carpio L./ larvae. Aquaculture. 161: 213-223.

Szatmári L. (2003): A magyar halászati ágazat elemzése a Hortobágyi Halgazdaság Rt. példáján. Doktori értekezés. Mosonmagyaróvár.

Szücs I. (2002): A halászati ágazat gazdasági, szervezési és piaci kérdései. Szaktudás Kiadó Ház. Budapest.

Tamás H.-L. Horváth G.-Tölg I. (1982): Tógazdasági tenyészanyag termelés. Mezőgazdasági Kiadó. Budapest. 259.

Verreth, J.-Torreele, E.-Spazier, E.-van der Sluiszen, A.-Rombout, J.-Booms, R.-Segner, H. (1992): The development of a functional digestive system in the African catfish Clarias gariepinus Burchell. Journal of the World Aquaculture Society. 23: 286-298.

Zakes, Z.-Szczepkowski, M. (2004): Induction of out-of-season spawning of pikeperch, Sander lucioperca (L.). Aquaculture International. 12: 11-18.

Zarsky, D.-Palinska-Zarska, K.-Luczynska, J.-Krejszeff, S. (2017): The type of spawning agent affects the egg composition during out-ofseason spawning but not during in-season spawning in Eurasian perch, (Perca fluviatilis). General and Comparative Endocrinology. 245: 19-29.

Zhang, D. (1994): Carp larvae culture using a recirculation system and feeding with live food. MSc Thesis. Wageningen University. Wageningen. 12. 